\title{
Socio-economic characteristics of the Cachoeira de Emas small-scale fishery in Mogi-Guaçu River, State of São Paulo, Brazil
}

\author{
Peixer, $J .^{\mathrm{a} *}$ and Petrere Júnior, $M .^{\mathrm{b}}$ \\ ${ }^{a}$ Centro Nacional de Pesquisa e Conservação de Peixes Continentais - CEPTA/ICMBio \\ Via Euberto N. Pereira de. Godoy, Km 6,5, CP 64, CEP 13641-001, Pirassununga, SP, Brazil \\ ${ }^{\text {b} D e p a r t a m e n t o ~ d e ~ E c o l o g i a, ~ U n i v e r s i d a d e ~ E s t a d u a l ~ P a u l i s t a ~-~ U N E S P, ~}$ \\ CP 199, CEP 13506-900, Rio Claro, SP, Brazil \\ *e-mail: janicepx@hotmail.com \\ Received May 14, 2008 - Accepted September 24, 2008 - Distributed November 30, 2009
}

(With 4 figures)

\begin{abstract}
Fishing in the area of Cachoeira de Emas dates from the aboriginal Painguás who inhabited its margins. The socioeconomic conditions of the fishers and fishing are described, derived from personal interviews with 33 fishers. Their mean age is 48.6 years and they have been fishing on average for 24.2 years. The monthly total raw income is US\$ 575.52 and the raw income just from fishing is of US\$239.64 per fisher. Most of them (66.6\%) have only incomplete primary and junior education. The main capture species are curimba Prochilodus lineatus, piapara Leporinus obtusidens, dourado Salminus brasiliensis, mandi Pimelodus maculatus, Pimelodus heraldoi and lambari (genus Astyanax and Roeboides). Fishers capture an average of $19.9 \mathrm{~kg}$ of fish per day. The total average raw income just calculated from the interviews is very high when compared with other places in Brazil and in the world, and above the poverty line as defined by the Getúlio Vargas Foundation. So we may conclude there these fishers are not the poorest in society.
\end{abstract}

Keywords: inland sub-tropical small-scale fishery, fishers' raw income, Mogí-Guaçu River, Brazil.

\section{Características socioeconômicas da pesca profissional de pequena escala na cachoeira de Emas, Rio Mogi-Guaçu, Estado de São Paulo (Brasil)}

\begin{abstract}
Resumo
A pesca na região da Cachoeira de Emas ocorre desde quando os indígenas habitavam suas margens. As condições socioeconômicas dos pescadores que atuam neste local e a caracterização da pesca foram determinadas através de entrevistas com 33 pescadores. A idade média deles é de 48,6 anos e eles vêm pescando em média por 24,2 anos. A renda mensal total familiar é de US\$ 575,52 e a renda apenas da pesca é de US\$ 239,64 por pescador. A maioria deles tem o primeiro grau incompleto $(66,6 \%)$. As principais espécies capturadas são o curimba Prochilodus lineatus, a piapara Leporinus obtusidens, o dourado Salminus brasiliensis, o mandi Pimelodus maculatus, Pimelodus heraldoi e o lambari (gênero Astyanax e Roeboides). Os pescadores capturam em média 19,9 kg por dia. Comparando-se a captura média diária por pescador na Cachoeira de Emas com outros lugares percebemos que ela ainda está acima da média. A renda média total está entre as mais altas comparando-se com outros locais do Brasil e do mundo e acima da linha de miséria definida pela Fundação Getúlio Vargas. Podemos então concluir que estes pescadores não são a classe de profissionais mais pobres da sociedade.
\end{abstract}

Palavras-chave: pesca profissional subtropical de pequena escala, renda dos pescadores, Rio Mogi-Guaçu, Brasil.

\section{Introduction}

The pressure upon the fishing stocks at world level has been steadily increasing over the last 30 years. The international fishing and fish products trade grew from US\$ 15 billion in 1980 to US\$ 56 billion in 2001 and in this period the developing countries increased their participation from 40 to $50 \%$, from less than US\$ 4 billion to nearly US\$ 18 billion (FAO, 2005).
The developed countries are the largest fish consumers $(90 \%)$ and most of it comes from small-scale marine fishing, inland fisheries, and from small-scale aquaculture (FAO, 2005).

Fishing and aquaculture all over the world employ about 38 million people that represent $2.8 \%$ of 1.33 billion people economically active in world agriculture. 
From this total, marine and inland fisheries represent $75 \%$ of the total number of workers. The greatest number of fishers and people working in aquaculture are in Asia (87\%), followed by Africa (7\%), Europe, North, Central and South America ( $2 \%$ each) and Oceania (0.2\%) (FAO, 2004).

In the west Indian Ocean area 320,000 people are involved in small-scale fisheries and 1,360,000 are involved in the fisheries secondary sector, represented by fish processing and sales (Walmsley et al., 2006). On the other hand, fishery management costs are continually increasing and the value of fishing production is declining as a consequence of the increasing landing of less valued species (Bninska and Wolos, 2001).

The governments of developing countries do not invest much in research and development of small-scale fisheries. This is so because the activity is seen as a social safety net, a cultural trait or a source of income and employment for those people of a lower level of instruction or less skilled for other tasks and not as an economical agent (Berkes et al., 2001). The fishing in Emas fits Sowman's (2006) classification as a small-scale fishery as it is a low investment fishery with few technological resources, using fishing methods that demand great physical effort, although we claim that this definition should also take into account the socio-cultural and local economical contexts

As in most rivers of the world, fishing in the MogíGuaçu River dates from the indigenous people, Painguás, who inhabited its margins (Schubart, 1949). From 1932 to 1946 , about 82 professional fishers were still active in the Cachoeira de Emas, a rapid where a small dam for electricity generation purposes was built, with a fish ladder (Schubart, 1949). Godoy (1974) notes that the number of professional fishers reached around 300 in the 50's and 60's, but from 1970-1974, there were only 30. In 1986, only 19 still active professional small-scale fishers were registered in an entity representing the class

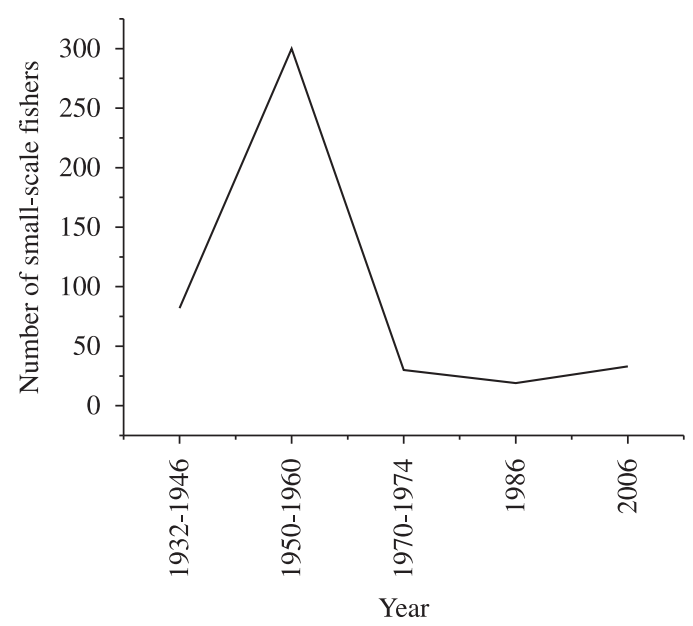

Figure 1. The number of professional small-scale fishers in Cachoeira de Emas over the years.
(Colônia de Pescadores Z-25) (Godoy, 1987). Figure 1 presents the variation of the number of fishers.

Schubart (1949) presented landing data collected from log-books between 1929 and 1935 and says that in this period the total production was $368 \mathrm{t}$. The most important species were curimba Prochilodus lineatus (Valenciennes, 1836), piracanjuba Brycon orbygnianus (Valenciennes, 1849) and dourado Salminus brasiliensis (Cuvier, 1816). Prochilodus lineatus accounted for more than $50 \%$ of the total catches. According to this author, Cachoeira de Emas was responsible for $47 \%$ of the fish caught in its river stretch.

This paper aims to present a diagnosis made of the socioeconomic situation of the professional fishers at Cachoeira de Emas, reporting their age, time in the activity, the monthly mean income, the previous occupation to fishing and their educational level. A list is presented of the commercially most important fish species, the best fishing months, the types of fish trade, fishing income, fishing gear and the most productive fishing spots.

\section{Material and Methods}

\subsection{Study area}

Mogi-Guaçu River headstreams are located in the State of Minas Gerais in the municipal district of Bom Repouso in the Mantiqueira mountain chain, at an altitude of 1,650 m. In the States of Minas Gerais and São Paulo (most of it), its total basin drainage area is $17,460 \mathrm{~km}^{2}$, (Brigante et al., 2002) (Figure 2). It is $473 \mathrm{~km}$ long up to its confluence with the Pardo River, in the Paraná basin. Just $5.9 \%$ of its natural vegetation remains.

In the Mogi-Guaçu River basin agricultural and industrial activities are intensive. The first is more notable in the state of Minas Gerais and the second in the state of São Paulo. As a consequence, the original riparian vegetation has virtually disappeared. Moreover, most of the municipal districts discard their domestic and industrial effluents into the river, with little or no treatment. The decline of many fish species, especially the piracanjuba Brycon orbygnianus, is a consequence of such disregard for the river's biotic integrity.

The waterfall of Emas (which in fact is a rapid) is located in the middle Mogi-Guaçu river and it gives the very name to the district in the municipality of Pirassununga, $7 \mathrm{~km}$ from downtown. There is a small dam built in the 20's for electric power generation, now out of operation.

\subsection{Methods}

In order to characterise professional small-scale fishery, interviews were carried out with the fishers still active in Emas, from January to July of 2006. In the interviews, we asked open and closed questions. As this is now a small and highly active community, the 33 professional fishers were surveyed with the exception of a fisherwoman who refused to be interviewed. Socioeconomic information was recorded related to age, length of time 


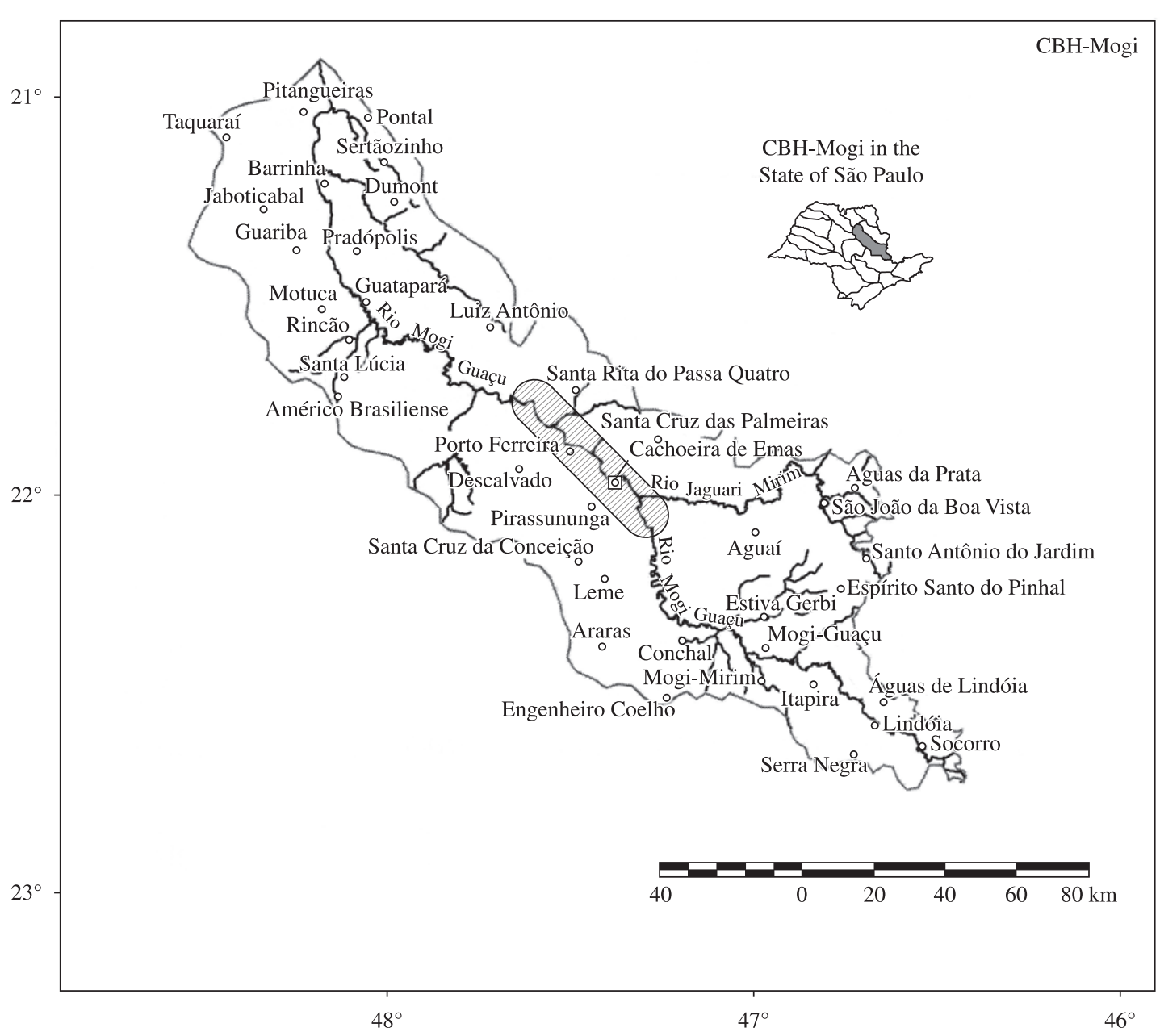

Figure 2. Location of river Mogí-Guaçu basin inside the State of São Paulo, with the fishing area surrounding Cachoeira de Emas. Adapted from CBH-Mogí and CREUP (1999).

professionally fishing, total family income and income from fishery, previous occupation to fishing, if the fisher has, or not, another activity, and their education level.

Regarding the fishers' informed current mean monthly raw income and the raw income in the past, it was not the objective of this paper to calculate fishers' earnings using the more precise methodology according to Ceregato and Petrere (2003), where the more realistic net profit from the fisheries is calculated using financial mathematics methodology. So the mean raw income should just be regarded as quick illustrative estimates.

In relation to fishing, the main information required was: main fishing sites, the main fish species, better fishing months, how the fish is commercialized, fishing income and fishing gear employed.

The informed mean catch refers to the last fished week, as the interviews were carried out during the fish- ing ban, the upriver fish migration, locally known as 'piracema'.

\section{Results}

\subsection{The socio-economic conditions of the Cachoeira de Emas fishers}

We interviewed 33 active fishers in Emas. The Colônia de Pescadores Z-25 includes 80 municipal districts including the main city (Pirassununga) and it has 1,200 fishers registered as professionals according to its President Mr. Joel Pereira Oliveira (personal communication to J.P.). This large number of fishers is due to the fact that the Colônia supplies licenses to people that are not professional fishers as they pay due taxes. Their benefit is that they can use some gear (mainly gillnets and castnets) not allowed for sporting fishers and get some social benefits. This is an unfair attitude and difficult to 
Table 1. Characteristics of Cachoeira de Emas fishers.

\begin{tabular}{lcccc}
\hline \multicolumn{1}{c}{ Variable } & Mean & $\begin{array}{c}\text { Standard } \\
\text { deviation }\end{array}$ & Range & n \\
\hline Age & 48.60 & 14.10 & $21-74$ & 33 \\
Years fishing & 24.20 & 15.48 & $2-52$ & $30^{1}$ \\
Total monthly family raw income (US\$) & 575.52 & 470.31 & $147.54-1967.25$ & 33 \\
Total monthly fishing raw income (US\$) & 239.64 & 107.87 & $54.1-590.17$ & $31^{2}$ \\
\hline
\end{tabular}

1Three fishers informed that they have fished since childhood; ${ }^{2}$ one fisher was unable to calculate raw income and another did not declare it.

avoid as it also benefits the President who is always seeking to be re-elected. Just one fisher was not registered in Z-25.

Table 1 presents the characteristics of the Emas fishers. Their mean age is 48.6 years and they fish on average for 24.2 years. The informed total family mean monthly raw income is US\$ 575.52 (US\$ $1=\mathrm{R} \$ 2.03$ - April 2007). The informed mean raw income just from fishery is US\$239.64 per fisher.

As displayed in Figure 3, some fishers have never had another profession (12.1\%), and $42.4 \%$ of them are former-employees of a cardboard factory which operated in the neighborhood of Cachoeira de Emas and which went bankrupt in 2000. Another profession which is quite important is that of bricklayer (or assistant). From these $63.6 \%(\mathrm{n}=21)$ have other activities such as selling fish, assisting tourists, and $30.3 \%(n=10)$, have other sources of income such as boarding house operators, house renting, etc.

Table 2 presents the fishers education level. As it may be seen, most of them just possess incomplete primary education.

\subsection{Small-scale fishery in Cachoeira de Emas}

Fishers act in an area of $25 \mathrm{~km}$ above and $40 \mathrm{~km}$ below Emas dam (Figure 2). Most of them usually fish above the dam (54.5\%), another portion below (12.1\%) and $33.3 \%$ fish above and below the dam, according to the dry and rainy seasons.

All of them fish in a partnership system, sharing costs and profits. They may change partners according to each other's will and availability. As fishing is accomplished mainly by cast nets and gillnets, there is the need of at least one more person in the boat. The most productive gear is the castnet $(75.8 \%)$. The best fishing months range from August to November during the upriver reproductive fish migration known locally as piracema.

According to Figure 4, the main capture species are $P$. lineatus (curimba), L. obtusidens (Valenciennes, 1836) (piapara), Salminus brasiliensis (dourado), mandi Pimelodus maculatus (LaCepède, 1803), Pimelodus heraldoi (Azpelicueta, 2001) and lambari (genus Astyanax and Roeboides). These figures were calculated when considering their fishery of the last week relative to the date of the survey. The only species that are not mentioned by any
Table 2. Education level of the professional fishers from Emas.

\begin{tabular}{lrr}
\hline \multicolumn{1}{c}{ Level of education } & n & \multicolumn{1}{c}{$\%$} \\
\hline Illiterate & 1 & 3.03 \\
First-grade education incomplete & 23 & 69.70 \\
First-grade education complete & 2 & 6.06 \\
Secondary education incomplete & 1 & 3.03 \\
Secondary education complete & 5 & 15.15 \\
Attending adult education courses & 1 & 3.03 \\
Total & 33 & 100 \\
\hline
\end{tabular}

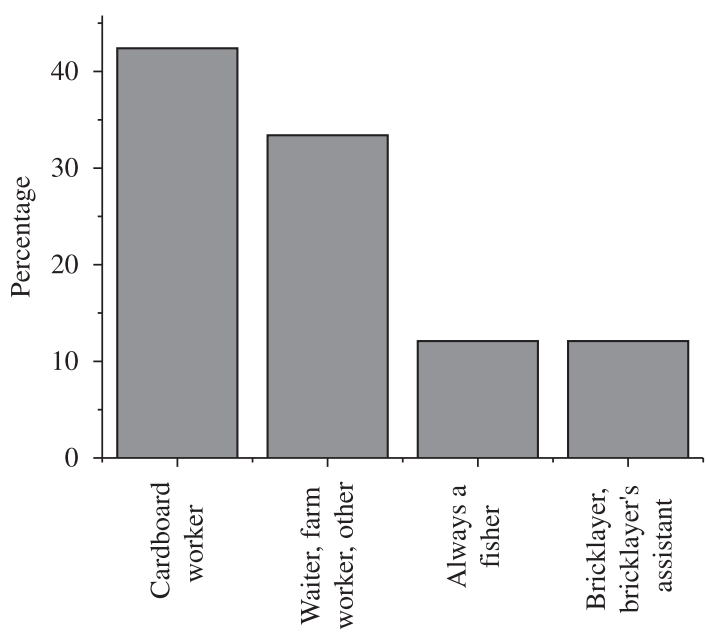

Emas fishers' previous activities before fishing

Figure 3. Emas fishers' previous activities before fishing.

fisher as rare ones are curimba, lambari and catfish bagresapo Pseudopimelodus mangurus (Valenciennes, 1840).

The main fish sale places are at the Sunday outdoor market on the river bank $(33.3 \% ; \mathrm{n}=11)$ or in the fishers' dwelling $(15.1 \% ; n=5)$. Some fishers also sell fish right on the edge of the SP-201 highway, on the ramp close to the bridge over the river Mogí-Guaçu $(9.1 \% ; n=3)$. Other combinations are the dwelling and the outdoor market $(9.1 \% ; \mathrm{n}=3)$, the ramp and the outdoor market $(6.1 \% ; n=2)$, or selling the fish to the restaurants and 
huts that sell fried fish in the outdoor market, on the river bank, etc $(27.3 \%$; $n=9)$. One of the fishers may be responsible for the sale of the production of some of his mates and daily sells the fish on the highway SP 201.

The outdoor market is frequented by the tourists that visit Emas for drinking and food and for observing fish jumping the ladder in the piracema. Fish is normally sold per unit, eviscerated and with scales.

As shown in Table 3, fishers capture on average $19.90 \mathrm{~kg}$ of fish per day with a maximum of $45 \mathrm{~kg} /$ day. They fish on average 6 hours a day and at the most for 10 hours. They fish on average for 4.7 days a week and at the most for 6 days.

Each fisher has its own gear, except two of them. Another fisher informed that he shares his gear with his partner. The fishers informed us that they use mainly gillnets and castnets. The castnet is considered the most productive (as it was mentioned by $75.8 \%$ of the fishers;

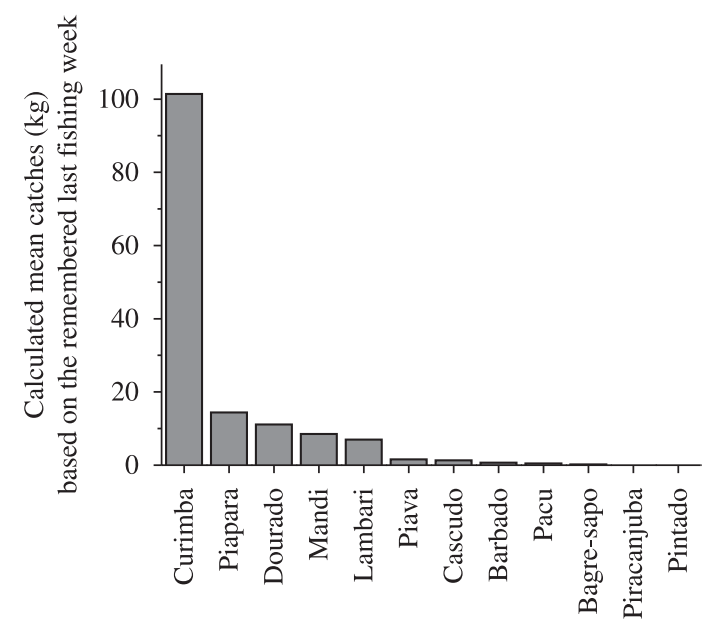

Species

Figure 4. Calculated mean catches $(\mathrm{kg})$ based on the remembered last fishing week by all fishers. Curimba (P. lineatus), piapara (Leporinus obtusidens), dourado (Salminus brasiliensis), mandi (Pimelodus maculatus, Pimelodus heraldoi, Pimelodella spp. (Eigenmann and Eigenmann, 1888), lambari (Astyanax fasciatus (Cuvier, 1819)), Astyanax schubarti (Britski, 1964), Roeboides paranensis (Pignalberi, 1975), Astyanax altiparanae) (Garutti and Britski, 2000), piava (Leporinus lacustris (Campos, 1945), Leporinus friderici (Bloch, 1794), Leporinus octofasciatus) (Steindachner, 1915), cascudo (Rhinelepis sp. (Spix, 1829), Megalancistrus parananus (Peters, 1881), Hypostomus spp. (Lacépède, 1803) (Lacépède, 1803)) (Agassiz in Spix and Agassiz, 1829), barbado (Pinirampus pirinampu) (Agassiz in Spix and Agassiz, 1829), pacu (Piaractus mesopotamicus) (Holmberg, 1887), bagre-sapo (Pseudopimelodus mangurus), piracanjuba (Brycon orbygnianus) and pintado (Pseudoplatystoma corruscans) (Agassiz in Spix and Agassiz, 1829). $\mathrm{n}=25)$. Most of them $(72.7 \%, \mathrm{n}=24)$ possess a motor boat. The others usually fish in their partner's boat.

In the dry season fishers build or usually repair walls made up of piled stones used to fish (Schubart, 1949). Not all of the fishers are proprietors of walls. There are 54 walls (3.6 per fisher). It seems that with the exception of these walls, there are no predetermined fishing spots for users, although just two fishers mentioned that in some points along the river bank, if any other fisher disrespects territoriality and sets his nets, the "owner" is free to remove the gear. Another two affirmed that in the fishing spots occupied by sporting fishers they avoid using the castnet. In the whole fishing stretch, there are 20 fishing spots above and 13 below the dam. Each one has its own name which in general, are easily identified rapids.

\section{Discussion}

\subsection{Socioeconomic conditions of the Cachoeira de Emas fishers}

In Cachoeira de Emas there are 33 active professional fishers, with just one of these being a woman. This characteristic is common in many other places like in the reservoirs of Barra Bonita and Jurumirim which are fished exclusively by fishermen (Mendonça, 2000); in the middle Amazon (Ruffino et al., 1999); in the municipal district of Barcelos (Silva, 2003); in the municipal district of Manicoré (Cardoso, 2005); in Lagoa Ibiraquera/ SC (Seixas, 2004) and in the area of the high-middle São Francisco River (Valencio et al., 2005) and in Tonga, in the South Pacific (Kronen, 2004). This reality is a little different in the Billings reservoir, located in the metropolitan area of São Paulo, where there was a considerable number of women (16.4\%) (Minte-Vera, 1997).

Many of the fishers registered in Colônia Z-25 are imposters, not being professional. Surely this is an illegal procedure as one of the obligations to bear a professional license is that this activity must be the fisher's profession or the main source of income (Fishery Law n 221 of February 28, 1967). Unfortunately this is a common situation in the fishers' Colony in Brazil.

The fishers' mean age is 48.6 years, similar to other areas in the country, which varies from 39.8 to 49.8 as in the Urubupungá reservoir area in the high Paraná River (Ceregato, 2001). About the same age range was verified in other parts of the country such as in Cáceres, in the Pantanal of Mato Grosso (Netto, 2006), in the middle Amazon (Ruffino et al., 1999), in the municipal district of Manicoré in Madeira River a substantial Amazon right margin affluent (Cardoso, 2005), on the São Francisco River (Camargo and Petrere, 2001). The mean age of fishers in Greece is 49 years (Tzanatos et al., 2006). In highly developed countries like Japan, it is 60 years as few young people are now interested in the activity. According to Tzanatos et al. (2006), the advanced age is one of the characteristics of the small-scale fisheries. 
Besides, old fishers may not have any social security and many continue in the activity, even lacking ideal physical conditions (Mendonça, 2000).

The time in the activity reflects the fisher's experience and the stability in the profession. In Emas this mean time is 24.2 years similar to that reported by Walter (2000) in Paranoá Lake in the capital city of Brasília where it is 22 years. In the municipal district of Barcelos in Negro River, the most important affluent (left margin) of the Amazon, it is 20.9 years (Cardoso, 2005). In the São Francisco River it ranges from 28-30 years (Camargo and Petrere, 2001) and in the high-middle São Francisco River, Valencio et al. (2005) report values between 10 to 53 years.

The informed monthly mean raw income of the fishers at Emas is quite high when compared to the data presented in Table 4. The largest income is the one related to Greek fishers; the smallest is related to middle Tocantins fishers. Considering the fishing income and comparing it to the figures in Table 4, the Emas fishers' raw income is much smaller than the one related to the Complexo Urubupungá fishers (Ceregato, 2001; Ceregato and Petrere, 2003) and similar to other places. Inspecting Table 4 and comparing Emas fishers' raw income to the poverty line defined by the Getulio Vargas Foundation (FGV, 2004), we see that it is well above this value. The situation of extreme poverty is that of the middle Tocantins fishers.

Most of the fishers in Emas originally worked in a cardboard factory which went bankrupt and due to the lack of jobs became fishers, a common pattern in the Third World. In the high Amazon, most of the fishers live from agriculture and many of them are old residents of rural areas who migrated to cities and did not find a job (Alencar, 2005). The fishers of the municipal district of Manicoré in Madeira River also came from rural communities (76.2\%) (Cardoso, 2005). In Paranoá Lake, most of the fishers came from the poor Northeast, on av-

Table 3. Catch per day, fishing time (hour/day) and days/week of the Emas professional fishers.

\begin{tabular}{llcccc}
\hline & \multicolumn{1}{c}{ Unit } & Mean & Standard deviation & Range & n \\
\hline Catch per day & $\mathrm{kg}$ & 19.90 & 9.85 & $3.20-45.00$ & 33 \\
Fishing time & hours per day & 6.00 & 1.71 & $3.00-10.00$ & 33 \\
Fishing time & days per week & 4.70 & 0.85 & $3.00-6.00$ & 33 \\
\hline
\end{tabular}

Table 4. Professional fishers' monthly mean income around the world.

\begin{tabular}{|c|c|c|c|}
\hline Region/country & US\$ & Reference & Observation \\
\hline Cachoeira de Emas & $\begin{array}{l}575.52 \text { (total) } \\
239.64 \text { (fishing) }\end{array}$ & This paper & $\begin{array}{l}63.3 \% \text { have other activities and } \\
30.3 \% \text { other sources of income }\end{array}$ \\
\hline Paranoá Lake/Brazil* & +156.48 & Walter, 2000 & Just fishing income \\
\hline $\begin{array}{l}\text { Billings reservoir/metropolitan } \\
\text { area of São Paulo - Brazil }\end{array}$ & $105.00-210.00$ & Minte-Vera, 1997 & $\begin{array}{l}\text { Fishing is the main activity } \\
\text { (Income of } 34 \% \text { of the fishers) }\end{array}$ \\
\hline $\begin{array}{l}\text { High-middle São Francisco River/ } \\
\text { Brazil* }\end{array}$ & 384.08 & Valencio et al., 2005 & $\begin{array}{l}\text { Fishing is the main source of } \\
\text { income }\end{array}$ \\
\hline Urubupungá1 reservoir/Brazil & $\begin{array}{l}\text { Net profit: } 339.50 \\
\text { Raw income: } 638.13\end{array}$ & $\begin{array}{l}\text { Ceregato, } 2001 \\
\text { Ceregato and } \\
\text { Petrere, } 2003\end{array}$ & $\begin{array}{l}\text { Just fishing income, albeit } \\
36.4 \% \text { of the fishers have other } \\
\text { living sources }\end{array}$ \\
\hline South Africa & 74.00 & Sowman, 2006 & $\begin{array}{l}50 \% \text { of the families have other } \\
\text { sources of income }\end{array}$ \\
\hline Greece & $1,169.11$ & Tzanatos et al., 2006 & $\begin{array}{l}50 \% \text { of the fishers have other } \\
\text { sources of income }\end{array}$ \\
\hline Middle Tocantins river/Brazil & 50.00 & $\begin{array}{l}\text { Cetra and Petrere, } \\
2001\end{array}$ & No further information \\
\hline Barra Bonita reservoir /Brazil* & 502.12 & Mendonça, 2000 & Whole family income \\
\hline Jurumirim reservoir/Brazil* & 110.54 & Mendonça, 2000 & Vegetable selling \\
\hline Balbina reservoir/Brazil & $<100.00$ & Freitas, et al., 2006 & Partial income from fishing \\
\hline Tucuruí reservoir/Brazil* & 146.14 & $\begin{array}{l}\text { Eletrobrás, c2003- } \\
2005\end{array}$ & No further information \\
\hline Poverty line ${ }^{2}$ & 53.25 & FGV, 2004 & \\
\hline
\end{tabular}

*These values were calculated from information originally expressed in minimum and transformed in current values. ${ }^{1}$ Calculations based on maximum values. Data supplied as daily income and transformed into monthly income, considering 30 fishing days; ${ }^{2}$ This value is based on a basket of food, where the daily consumption is of 2,288 calories (value recommended by WHS) FGV (2004). 
erage 21.7 years ago and now live in the Federal District or in its surroundings (Walter and Petrere, 2007).

Most of the fishers are only part-time with other activities to complement the family income. Other fishers are retired and continue in the activity because the retirement pension is not sufficient to provide for the family. In Paranoá Lake, $47.6 \%$ of the fishers live exclusively from fishing, others are merchants $(9.5 \%)$, or have a proper job (9.5\%) and others are autonomous (33.3\%) working as bricklayers, electricians, painters, etc. (Walter, 2000; Walter and Petrere, 2007). In the northeastern area of Nigeria most of the fishers are part timers and less than $5 \%$ of the families have fishing as the only source of income fishing for less than six months a year (Neiland et al. 2000). In Greece, most of the fishers depend exclusively on fishing (64.4\%) (Tzanatos et al., 2006). Fishing is usually a part-time activity in marine or freshwater small-scale fisheries (60\%) and this is due to the seasonal variation of the fishing resources and fishing regulations (FAO, 2004). According to Arlinghaus et al. (2002), full-time commercial fishery is vanishing in developed countries such as in North America, Belgium and England although it is still economically viable and has local importance in some countries of Europe such as in Finland, France and Poland.

Regarding the fishers' education level, most are illiterate or possess incomplete primary-junior education; few have completed secondary education or are still studying (Table 5). Ceregato (2001) found a similar pattern in Urubupungá Lake, where $5.5 \%$ of the interviewed fishers are illiterate, $3.4 \%$, are only able to write their names and most had either complete or incomplete primary-junior education. In the low São Francisco River the situation is even worse as $50 \%$ are illiterate or semi-literate and the others have a low education level (Camargo and Petrere, 2001). In Greece, fishers' education is also low when compared to non-fishers (Tzanatos et al., 2006).

\subsection{Small-scale fishery in Cachoeira de Emas}

The fishers at Emas fish in a stretch of river of $65 \mathrm{~km}$ in the river Mogí Guaçu. They go along the river looking for shoals in order to increase fish production. This extension is comparatively larger than the one of the Paranoá Lake (in Brasília DC), where fishers move $2.5 \mathrm{~km}$ on average and at the most $18 \mathrm{~km}$ (Walter, 2000).

Fishers act in partnership in order to share their fishing gear and for other economical and social conditions. A similar situation also takes place at Paranoá Lake where only $7.5 \%$ of the fishers fish alone, most of them fishing in partnership with a friend or a relative sharing the gear. Those pairs are not fixed because of conflicts and due to the instability inherent to the profession (Walter and Petrere, 2007). So the pairs in Emas are also not always constant.

The best fishing months extend from August to November when the shoals that go up river to spawn begin to arrive at Emas. This is an important reproduction area and it is in this period that the fishers get better income. Many fishers commented that if fishing were allowed in the piracema (November to February), it would be the most productive season. They don't fish during the fishing ban, which usually starts on November $1^{\text {st }}$. Obviously there is clandestine fishery which is not part of this work. So officially, as they do not fish in this period they are put on the dole.

Moreover, just after the ban, in March and April, there occurs a late ascent of $P$. lineatus schools locally known as "temporão" (Capeleti and Petrere, 2006). Even so, the month of March is not cited as one of the best fishing months.

According to their information in the last week before the ban, the P. lineatus is the most important species, followed by L. obtusidens, S. brasiliensis, P. maculatus and lambari (genus Astyanax and Roeboides). The other species practically do not show up. Capeleti and Petrere (2006) estimated that $34 \%$ of the total fish counted jumping the dam, during the reproductive migration, were represented by P. lineatus. On the other hand Brycon orbygnianus, which previously was cited as very abundant, is virtually not cited anymore.

Barbieri et al. (2000) reported that $S$. brasiliensis and $P$. lineatus appear all year round, not only in the reproductive period, and the same information was given by Esteves and Pinto Lobo (2001) concerning the dourado. In other words, the fishers at Emas have a period of greater income near the piracema but for the rest of the year, the specimens that do not leave this area sustain the fishery.

Ihering (1929), describing fishery at Emas, noted that then, the most important landed species were P. lineatus, Leporinus friederici, Pimelodus maculatus, Pseudopimelodus mangurus, cascudos (Rhinelepis sp., Megalancistrus paranananus Hypostomus spp)., as well as surubim Steindachneridion scriptum (Miranda Ribeiro, 1918), Brycon orbignyanus and Salminus brasiliensis. Comparatively, for the Parana basin, the main species caught in Piracicaba River are P. lineatus, alien corvina Plagioscion squamosissimus (Heckel, 1840), P. maculatus, cascudos (Liposarcus aff. anisitsi) (Eigenmann and Kennedy, 1903), lambari (Astyanax spp. (Baird and Girard, 1854), Moenkhausia intermedia (Eigenmann, 1908) and juveniles Triportheus signatus) (Garman, 1890) and traíra (Hoplias malabaricus) (Bloch, 1794) (Silvano and Begossi, 2001). The most caught species during the rainy season in Rio Grande is the P. lineatus; in the months of transition (April to October) the Pimelodus maculatus and in the dry season the $P$. lineatus again is the most important (Castro and Begossi, 1995).

All the human interventions which have taken place in the Mogi-Guaçu River basin and in Grande River, have certainly contributed to the decreasing fish diversity and abundance. According to Godoy (1975), the dam building of Cachoeira de Marimbondo and Porto Colômbia in mid Grande River, reduced the feeding grounds of curimba from about $220 \mathrm{~km}$ to $126 \mathrm{~km}$. Toledo et al (1987) con- 
firmed this as delimiting the occurrence of the $P$. lineatus in the basin. In the 70's Godoy (1974) already mentioned the decline of the Mogi-Guaçu River fish stocks, mainly of $S$. brasiliensis and Brycon orbignyanus, associating it to inadequate land use. Morais Filho and Schubart (1955) also mentioned a decrease in the S. brasiliensis mean length since 1935 associating this finding to the intense fishing, deforestation, pollution, floodplain drainage, etc.

In many cases, the fish commercialization chain is among the longest of the primary section and, added to this is the fact that fish are highly perishable, imposing an urgency for sale, resulting in a high discrepancy between the fisher's very low income when compared with the people that distribute and market the fish (Cardoso, 2001). However, in Emas, unlike most other places, the middleperson does not exist. The whole fish is marketed directly to the consumer. This results in better earnings for the fisher. The presence of tourists and the easy access to the highway, makes the fish trade quick and easy.

Most of the fish are not prepared for sale, just the viscera are removed. In Paranoá Lake this practice is also common, the only difference is that they take the scales away (Walter and Petrere, 2007). In Africa and Asia, most of the fish is consumed alive or fresh. In Africa, a great part of it is smoked and in Europe and North America it is frozen and canned (FAO, 2004). In general, freezing represents the main (53\%) method of processing fish for human consumption, followed by preservation $(27 \%)$ and salting (20\%).

The mean daily catch at Emas is above the average when compared to other places (Table 6), including the Pantanal, a much larger and better preserved area. This mean catch increased in relation to the data of 1994 (in

Table 5. Comparison of the level of education of professional fishers in several places in Brazil (\%)

\begin{tabular}{|c|c|c|c|c|c|}
\hline Region & Illiterate & $\begin{array}{c}1^{\circ} \text { grade } \\
\text { incomplete }\end{array}$ & $\begin{array}{l}1^{\circ} \text { grade } \\
\text { complete }\end{array}$ & $\begin{array}{c}2^{\circ} \text { grade } \\
\text { (studying, } \\
\text { incomplete, } \\
\text { complete) }\end{array}$ & Reference \\
\hline Cachoeira de Emas & 0.3 & 66.60 & 0.60 & 1.81 & This paper \\
\hline Paranoá Lake/Brazil & 21.1 & 53.80 & - & 3.80 & Walter and Petrere, 2007 \\
\hline Billings Reservoir/Brazil & 5.4 & 83.50 & - & - & Minte-Vera, 1997 \\
\hline $\begin{array}{l}\text { Barra Bonita and } \\
\text { Jurumirim Reservoirs/ } \\
\text { Brazil }\end{array}$ & 18.4 & $\begin{array}{c}50.00 \\
5.26 \\
\text { (still studying) }\end{array}$ & 15.76 & 7.90 & Mendonça, 2000 \\
\hline $\begin{array}{l}\text { Manicoré Municipality/ } \\
\text { Brazil }\end{array}$ & 22 & 63.40 & - & - & Cardoso, 2005 \\
\hline $\begin{array}{l}\text { Três Marias Reservoir/ } \\
\text { Brazil }\end{array}$ & $+60 \%$ & & - & - & Agostinho et al., 2007 \\
\hline Tucuruí Reservoir/Brazil & 40 & 30.00 & - & - & (Eletrobrás, 2003-2005) \\
\hline $\begin{array}{l}\text { Bellow Tucuruí Reservoir/ } \\
\text { Brazil }\end{array}$ & 40 & 30.00 & - & - & (Eletrobrás, 2003-2005) \\
\hline
\end{tabular}

Table 6. Professional fishers' mean catches in several places in Brazil.

\begin{tabular}{lcl}
\hline \multicolumn{1}{c}{ Site } & $\begin{array}{c}\text { Mean catch } \\
(\mathbf{k g} / \text { fisher/day })\end{array}$ & \multicolumn{1}{c}{ Reference } \\
\hline Cachoeira de Emas & 19.90 & This paper \\
Cachoeira de Emas (1994) & 15.00 & Vermulm et al., 2001 \\
Cachoeira de Emas & $40.00-50.00$ & Ihering (1929) \\
Pantanal de Cáceres & 5.72 & Netto, 2006 \\
Paranapanema River & 12.00 & Vermulm et al., 2001 \\
Paraná River & 21.50 & Vermulm et al., 2001 \\
Lago Grande de Monte Alegre (middle Amazon) & 17.00 & Ruffino et al., 1999 \\
Balbina reservoir & 33.00 & Santos and Oliveira, 1999 \\
Grande River & 10.00 & Castro and Begossi, 1995 \\
Piracicaba River & 27.00 & Silvano and Begossi, 2001 \\
Overall mean (except Cachoeira de Emas) & 17.96 & \\
\hline
\end{tabular}


this period 33 fishers were also active; Vermulm et al. 2001) but when compared to the historical Ihering (1929) production, it decreased very much. This is expected after almost 80 years of intense agricultural and industrial activity in the whole basin in the Mogí-Guaçu River. In spite of that, the area at Emas is still capable of sustaining a small-scale fishery comparable to other places as the municipal district of Alenquer (Amazon area) related to dourada (Brachyplatystoma rousseauxii) (Castelanau, 1855) fishing, where fishers working in pairs may catch up to $40 \mathrm{~kg}$ per day in the high season, but in the rest of the year, they catch 15 to $20 \mathrm{~kg}$ per day (Mitlewski et al., 1999). In the Pantanal of Mato Grosso do Sul, Catella (2001) estimated the mean catch of the professional fishers at $12.5 \mathrm{~kg}$ per day. In the Pantanal of Cáceres the fishing trips last on average 4.8 days, when fishers come back home with $27.4 \mathrm{~kg}$ of fish (Netto, 2006). In relation to the river São Francisco, Emas is in better fishing conditions when compared to the data of the Fisher's Colony of Pirapora (MG) Z-1, where they caught $11.7 \mathrm{~kg} /$ fisher/day in 1987 (Godinho et al., 1997) and in 1999 only $3.1 \mathrm{~kg} /$ fisher/day (Fundep, 2000 apud Godinho and Godinho, 2003).

Unfortunately the papers mentioned above do not inform the amount of fishing hours per day. In Cachoeira de Emas fishers usually work about 6 hours and for example in Porto São José, fisheries last 13.3 hours/day (Carvalho, 2002). The reason for this is that the fishers reside near the fishing sites and when they reach their daily catch goal or when they believe that on a particular day, fishing will not be productive, they stop fishing and come back home.

Among the permitted fishing gear the gillnet is the most common albeit the castnet is unanimously considered as the most productive. In this stretch with many rapids, other types of gear clearly cannot be employed. The use of gillnets and castnets are also common in other places in the small-scale inland fisheries in the state of São Paulo, where $98 \%$ of the fishers use the gillnet, as well as the castnet and the longline (Santos et al., 1995). These authors associated the predominance of the gillnet to the great number of dams in the state. Fishers in Rio Grande use mainly castnets and longlines (Castro and Begossi, 1995). A very different reality is verified in the Pantanal do Mato Grosso do Sul, where the professional fishers, due to the pressure of sports fishing, are only allowed to use line and hook, except tiny nets for catching small fish used as bait. In Negro River (Amazon basin), riverine populations use harpoons, long lines and poles (Silva, 2003). In Tonga, South Pacific, fishers use harpoons, hand lines and several sorts of nets (Kronen, 2004). In the northeast area of Nigeria, 17 types of fishing gear are used, among them nets and some traditional ones such as baskets (Neiland et al. 2000). Welcomme (1985) shows a list of fishing gears of small-scale inland fisheries.

In some cases, rules, rights and norms are used to regulate the access to certain resources (Begossi, 1998).
This is the case of the fishing walls near Emas, which are the fishing spots where the fishing territory is well defined and recognised. The points in the riverbanks mentioned by only two fishers are not common and so they are not recognised as fishing territories. Wall building is an old fishing strategy registered for the first time by Schubart (1949) and still persists. The fishers respect each others' walls and all know their 'owners'. There is no need to defend them, the rules for their use are of common domain and all respect them. These walls are transferred from father to son and in some cases they are marketed or donated. One of the fishers interviewed has owned a wall for 40 years! In the municipal district of Buritizeiro (São Francisco River) there is an ownership system of large stones in the rapids and fishers operate in turns (Thé et al. 2003). According to this author, there is the acquired right, the right for consent, the right for purchase and right from inheritance. This same division can be observed in the walls of Emas.

The fishing spots in the area of Emas are recognised from their physical characteristics and there is no conflict for their use. Begossi (2004) defines fishing spots as fishers' areas of common use and when there are rules for their use, or there exist use conflicts, they are treated as a territory. In those cases in which many fishing spots are available and the fishing gears are movable, there is no territory defense (Begossi, 1998).

Emas possesses peculiar characteristics which demand that the laws which rule its fisheries are differentiated and that they take into account the wishes of the fishers who have been there for many years. According to Berkes et al. (2001), the fish officers responsible for stock management must be creative and always try to innovate, as there is no single rule for a fishery or for an ecosystem because each place or human community is unique.

An idea that always appears as an alternative to decreasing fishing effort is that of implanting incentive projects inducing fishers to abandon their profession. The idea that the fishers might easily change from their original activity is based on several suppositions (as stated by scientists and fisheries officers in developing countries): i) fishing is a last option; ii) fishers are the poorest among the poor; iii) fishing is a despicable profession, difficult and undesirable; and iv) that the poor people care little about their profession (Pollnac et al., 2001). McGoodwin (1990) reviewed the literature on this subject and concluded that the fishers usually continue their activity even with diminishing catches, and therefore income, and this puzzles fisheries officers and economists because they do not understand non-economical professional satisfaction. In the Philippines, Indonesia and Vietnam, most of the fishers are not ready to change their profession for other activities of a similar income, as they are satisfied with their work and are not the poorest among the poor (Pollnac et al., 2001).

The fishers at Emas also feel satisfaction with their work, although they feel forced to develop other activi- 
ties to provide for their family needs. If the income from fishing were sufficient for such provision, they would just opt for fishing and for the free life characteristic of the activity.

Acknowledgements - We are grateful to the professional fishers who patiently answered the questionnaires. To CEPTA for the facilities and financial support. To UNESP for the facilities and for $\mathrm{CNPq}$ who also partially financed this research. Dr. José Augusto Senhorini introduced us to the Cachoeira de Emas professional fishers. Dr. Flávio César Thadeo de Lima of MZUSP identified the fish.

\section{References}

AGOSTINHO, AA., GOMES, LC. and PELICICE, FM., 2007. Ecologia e manejo de recursos pesqueiros em reservatórios do Brasil. Maringá: Eduem. 501 p.

ALENCAR, EF., 2005. Políticas públicas e (in)sustentabilidade social: o caso de comunidades da Várzea do Alto Solimões, Amazonas. In LIMA, D. (Org.). Diversidade socioambiental nas Várzeas dos Rios Amazonas e Solimões: perspectivas para o desenvolvimento da sustentabilidade. Brasília: IBAMA. p. $59-100$.

ARLINGHAUS, R., MEHNER, T. and COWX, IG., 2002. Reconciling traditional inland fisheries management and sustainability in industrialized countries, with emphasis on Europe. Fish and Fisheries, vol. 3, no. 4, p. 261-316.

BARBIERI, G., SALLES, FA. and CESTAROLLI, MA., 2000. Influências de fatores abióticos na reprodução do dourado, Salminus maxillosus e do curimbatá, Prochilodus lineatus do Rio Mogi Guaçu (Cachoeira de Emas, Pirassununga/SP). Acta Limnologica Brasileira., vol. 12, no. 2, p. 85-91.

BEGOSSI, A., 1998. Property rights for fisheries at different scales: applications for conservation in Brazil. Fisheries Research, vol. 34, no. 3, p. 269-278.

2004. Áreas, pontos de pesca, pesqueiros e territórios na pesca artesanal. In BEGOSSI, A. (Org.). Ecologia de pescadores da Mata Atlântica e da Amazônia. São Paulo: Editora Hucitec. p. 223-253.

BERKES, F., MAHON, R., McCONNEY, P., POLLNAC, R. and POMEROY, R., 2001. Managing small-scale fisheries: alternative directions and methods. Ottawa: IDRC Books free online. Available from: <http://www.idrc.org.sg/em/ev-9328201-1DO_TOPIC.html>. Access in: March 2006.

BNINSKA, M. and WOLOS, A., 2001. Management of selected Polish commercial and recreational lake fisheries activities. Fisheries Management and Ecology, vol. 8, no. 4-5, p. 333-343.

BRIGANTE, J., ESPÍNDOLA, ELG., POVINELLI, J., ELER, MN., SILVA, MRC., DORNFELD, CB. and NOGUEIRA, AM., 2002. Avaliação ambiental do Rio Moji-Guaçu: resultados de uma pesquisa com abordagem ecossistêmica. São Carlos: Rima. $58 \mathrm{p}$.

CAMARGO, SAF. and PETRERE Jr., M., 2001. Social and financial aspects of the artisanal fisheries of Middle São Francisco River, Minas Gerais, Brazil. Fisheries Management and Ecology, vol. 8, no. 2, p. 163-171.

CAPELETI, AR. and PETRERE Jr., M., 2006. Migration of the curimbatá Prochilodus lineatus (Valenciennes, 1836) (Pisces,
Prochilodontidae) at the waterfall "Cachoeira de Emas" of the Mogi-Guaçu River - São Paulo, Brazil. Revista Brasileira de Biologia $=$ Brazilian Journal of Biology, vol. 66, no. 2B, p. 651-659.

CARDOSO, ES., 2001. Pescadores artesanais: natureza, território, movimento social. São Paulo: Universidade de São Paulo. 143 p. [Tese de Doutorado].

2005. A pesca comercial no Município de Manicoré (Rio Madeira), Amazonas, Brasil. Manaus: Universidade Federal do Amazonas. 125 p. [Dissertação de Mestrado].

CARVALHO, AR., 2002. Valoração econômico-ecológica da Planície de inundação do Alto rio Paraná. Maringá: Universidade Estadual de Maringá. 139 p. [Tese de Doutorado]

CASTRO, F. and BEGOSSI, A., 1995. Ecology of fishing on the Grande River (Brazil): technology and territorial rights. Fisheries Research, vol. 23, no. 3-4, p. 361-373

CATElla, AC., 2001. A pesca no Pantanal de Mato Grosso do Sul, Brasil: descrição, nível de exploração e manejo (19941999). Manaus: Universidade do Amazonas. 351 p. [Tese de Doutorado].

CEREGATO, SA., 2001. Comparação bioeconômica das pescarias artesanais realizadas no Complexo de Urubupungá e a sua jusante no Rio Paraná. Rio Claro: Universidade Estadual Paulista. 129 p. [Tese de Doutorado]

CEREGATO, SA. and PETRERE Jr., M., 2003. Financial comparisons of the artisanal fisheries in Urubupungá Complex in the middle Paraná River (Brazil). Revista Brasileira de Biologia = Brazilian Journal of Biology, vol. 63, no. 4, p. 673-682.

CETRA, M. and PETRERE Jr., M., 2001. Small-scale fisheries in the middle River Tocantins, Imperatriz (MA), Brazil. Fisheries Management and Ecology, vol. 8, no. 2, p. 153-162.

ELETROBRÁS. Recursos pesqueiros, pescadores, Tucuruihidrelétrica e Furnas: condições de vida dos pescadores locais. Brasília: Eletrobrás. Available from: <http://www.eletrobrás. com.br>. Access in: April 2007.

ESTEVES, KE. and PINTO-LOBO, AV., 2001. Feeding pattern of Salminus maxillosus (Pisces, Characidae) at Cachoeira das Emas, Mogi-Guaçu River (São Paulo State, Southeast Brazil). Revista Brasileira de Biologia = Brazilian Journal of Biology, vol. 61 , no. 2, p. $267-276$

Food and Agriculture Organization - FAO, 2004. The state of world fisheries and aquaculture. Rome: FAO. Available from: <http://www.fao.org/DOCREP/007/Y5600/Y5600E05.htm>. Access in: March 2007.

2005. Increasing the contribution of small-scale fisheries to poverty alleviation and food security. Rome: FAO technical guidelines for responsible fisheries. 79 p. (no. 10).

Fundação Getúlio Varghas - FGV, 2004. Evolução recente da miséria. Rio de Janeiro: Centro de Políticas Sociais do Instituto Brasileiro de Economia. Available from: <http://www.fgv.br/ ibre/cps/pesq_recentes/Texto\%20Principal.pdf $>$. Access in: March 2007

FREITAS, CEC., RIVAS, AFA., NASCIMENTO, FA., SIQUEIRA-SOUZA, FK. and SANTOS, ILA., 2006. The effects of sport fishing growth on behavior of commercial fishermen in Balbina reservoir, Amazon, Brazil. Environment, Development and Sustainability, vol. 10, no. 3, p. 157-165. 
Fundação de Desenvolvimento da Pesquisa - FUNDEP, 2000. Programa de pesquisa e ações para conservação e restauração de recursos pesqueiros de Minas Gerais. Belo Horizonte: FUNDEP. 65 p.

GODINHO, HP., MIRANDA, MOT., GODINHO, AL. and SANTOS, JE., 1997. Pesca e biologia do surubim Pseudoplatystoma coruscans no rio São Francisco. In MIRANDA, MOT. (Org.). Surubim. Brasília: IBAMA. p. 27-42. (Série Estudos Pesca/Coleção Meio Ambiente, no. 19).

GODINHO, AL. and GODINHO, HP., 2003. Breve visão do São Francisco. In GODINHO, HP. and GODINHO, AL. (Eds.). Águas, peixes e pescadores do São Francisco das Minas Gerais. Belo Horizonte: PUC Minas. p. 15-24.

GODOY, MP., 1974. Contribuição à história natural e geral de Pirassununga. Pirassununga. Manuscrito. 218 p. (vol. 1).

1975. Peixes do Brasil: subordem Characoidei, Bacia do Rio Mogi Guassu. Piracicaba: Editora Franciscana. 216 p. (vol. 1).

1987. A escada de peixes de Cachoeira de Emas, Rio Mogi Guassu, Estado de São Paulo, Brasil. Porto Alegre: PUCRS. p. 139-151. (Comunicações do Museu de Ciências e Tecnologia da PUCRS, no. 43)

KRONEN, M., 2004. Fishing for fortunes? A socio-economic assessment of Tonga's artisanal fisheries. Fisheries Research, vol. 70 , no. 1, p. 121-134.

IHERING, RV., 1929. Da vida dos peixes: ensaios e scenas de pescarias. São Paulo: Editora Proprietária. 150 p.

McGOODWIN, JR., 1990. Crisis in the world's fisheries: people, problems, and policies. Stanford: Stanford University Press. 253 p.

MENDONÇA, SAT., 2000. Pescadores-barrageiros: perfil profissional e condições de vida no interior paulista. Rio Claro: Universidade Estadual Paulista. 119 p. [Dissertação de Mestrado].

MINTE-VERA, CV., 1997. A pesca artesanal no Reservatório Billings (São Paulo). Campinas: Universidade Estadual de Campinas. 84 p. [Dissertação de Mestrado].

MITLEWSKI, B., MACHADO-FILHO, F., QUEIROZ-FILHO, ESP., SANTANA, AC., MOREIRA, AJF., MELLO, RQ., BONATTO, MPO., MOTA, SQC. and STEVENS, AD., 1999. Estudo de caso em Centro Comercial, Município de Alenquer, PA. In Recursos pesqueiros do Médio Amazonas: abordagem socioeconômica. Brasília: IBAMA. p. 251-320. (Série Estudos Pesca/Coleção Meio Ambiente, no. 21).

MORAIS-FILHO, MB. and SHUBART, O., 1955. Contribuição ao estudo do dourado (Salminus maxillosus Val.) do Rio Mogi Guassu (Pisces, Characidae). São Paulo: Revista dos Tribunais Ltda. $131 \mathrm{p}$.

NEILAND, AE., JAFFRY, S., LADU, BMB., SARCH, MT. and MADAKAN, SP., 2000. Inland fisheries of North East Nigéria including the Upper River Benue, Lake Chad and the NguruGashua wetlands I. Characterisation and analysis of planning suppositions. Fisheries Research, vol. 48, no. 3, p. 229-243.

NETTO, SL., 2006. Pesca profissional versus pesca esportiva: suas diferenças e semelhanças no Pantanal Matogrossense, Brasil. Cuiabá: Universidade Federal de Mato Grosso. 47 p. [Dissertação de Mestrado].
POLLNAC, RB., POMEROY, RS. and HARKES, IHT., 2001. Fishery policy and job satisfaction in three southeast Asian fisheries. Ocean and Coastal Management, vol. 44, no. 7-8, p. 531-544.

RUFFINO, ML., MITLEWSKI, B., ISAAC, VJ. and OLIVEIRA, PRS., 1999. Lago Grande de Monte Alegre: uma análise das suas comunidades pesqueiras. In Recursos pesqueiros do Médio Amazonas: abordagem socioeconômica. Brasília: IBAMA. p. 31-756. (Série Estudos Pesca/Coleção Meio Ambiente, no. 21).

SANTOS, RA., CAMARA, JJC., CAMPOS, EC., VERMULM Jr., H. and GIAMAS, MTD., 1995. Considerações sobre a pesca profissional e a produção pesqueira em águas continentais do Estado de São Paulo. Boletim Técnico do Instituto de Pesca, no. $19,32 \mathrm{p}$.

SANTOS, GM. and OLIVEIRA Jr., AB., 1999. A pesca no reservatório da hidrelétrica de Balbina (Amazonas, Brasil). Acta Amazônica, vol. 29, no. 1, p. 145-163.

SCHUBART, O., 1949. A pesca no Mogi-Guassú. Revista do Arquivo, n. CXXII, 166 p.

SEIXAS, CS., 2004. Instituições e manejo pesqueiro: o caso da Lagoa de Ibiraquera, SC. In BEGOSSI, A. (Org.). Ecologia de pescadores da Mata Atlântica e da Amazônia. São Paulo: Editora Hucitec. p. 285-312.

SILVA, AL. 2003., Uso de recursos por populações ribeirinhas do Médio Rio Negro. São Paulo: Universidade de São Paulo. 220 p. [Tese de Doutorado].

SILVANO, RAM. and BEGOSSI, A., 2001. Seasonal dynamics of fisheries at the Piracicaba River (Brazil). Fisheries Research, vol. 51, no.1, p. 69-86.

SOWMAN, M., 2006. Subsistence and small-scale fisheries in South Africa: a ten-year review. Marine Policy, vol. 30, no.1, p. 60-73.

THÉ, APG., MADI, EF. and NORDI, N., 2003. Conhecimento local, regras informais e uso do peixe na pesca do Alto-Médio São Francisco. In GODINHO, HP. and GODINHO, AL. (Orgs.). Águas, peixes e pescadores do São Francisco das Minas Gerais. Belo Horizonte: PUC Minas. p. 389-406.

TOLEDO, SA., GODOY, MP. and SANTOS, EP., 1987. Delimitação populacional do curimbatá, Prochilodus scrofa (Pisces, Prochilodontidae) do Rio Mogi-guaçu, Brasil. Revista Brasileira de Biologia = Brazilian Journal of Biology, vol. 47, no. 4 , p. 501-506.

TZANATOS, E., DIMITRIOU, E., PAPAHARISIS, L., ROUSSI, A., SOMARAKIS, S. and KOUTSIKOPOULOS, C., 2006. Principal socio-economic characteristics of the Greek small-scale coastal fishermen. Ocean and Coastal Management, vol. 49 , no.7-8, p. 511-527.

VALÊNCIO, NFLS., MENDONÇA, SAT. and MARTINS, RC. 2005. Ação institucional e violência simbólica na pesca profissional artesanal do Rio São Francisco. In ESPÍNDOLA, ELG. and WENDLAND, E. (Orgs.). PPG-SEA: trajetórias e perspectivas de um curso multidisciplinar. São Carlos: Rima. p. $175-202$

VERMULM Jr, H., GIAMAS, MTD., CAMPOS, EC., CAMARA, JJC. and BARBIERI, G., 2001. Avaliação da pesca extrativa em alguns rios do Estado de São Paulo, no período entre 1994 e 1999. Boletim do Instituto de Pesca, vol. 27, no. 2, p. 209-217. 
WALMSLEY, S., PURVIS, J. and NINNES, C., 2006. The role of small-scale fisheries management in the poverty reduction strategies in the Western Indian Ocean region. Ocean and Coastal Management, vol. 49, no. 11, p. 812-833.

WALTER, T., 2000. Ecologia da pesca artesanal no Lago Paranoá, Brasília, DF. São Carlos: Universidade de São Paulo. 230 p. [Dissertação de Mestrado].
WALTER, T. and PETRERE Jr., M., 2007. The small-scale urban reservoir fisheries of Lago Paranoá, Brasília, DF, Brazil. Revista Brasileira de Biologia = Brazilian Journal of Biology, vol. 67, no.1, p. 9-21.

WELCOMME, R., 1985. River fisheries. Rome: FAO Fisheries Technical Paper. 330 p. 